\title{
Vocabulary Learning via Reading: Is Input Modification Useful?
}

\author{
Mojgan Rashtchi \\ TEFL Department, Faculty of Foreign Languages, Islamic Azad University, North Tehran Branch, Iran \\ Reza Porkar \\ TEFL Department, Faculty of Foreign Languages, Islamic Azad University, North Tehran Branch, Iran
}

\begin{abstract}
Since authentic texts address native speakers, they might lack the reader-friendly attributes which can help EFL learners to read and understand them. Also, learning the new vocabulary through reading can be difficult for EFL learners. As such, in order to utilize these texts as teaching materials in EFL classes, they should be modified. The present study investigated Iranian intermediate-level EFL learners and how they acquire English language vocabulary incidentally from modified English texts while their primary task is reading for meaning. In order to measure the impact of lexical input modification on the improvement of foreign language vocabulary learning, 60 adult Iranian EFL learners between the ages of 18 and 22 in two intact classes were selected and randomly assigned to two homogenous groups of control and experimental. The analysis of the data revealed that incidental second language vocabulary learning could be improved effectively by lexical input modifications such as lexical and typographical elaboration.
\end{abstract}

Index Terms—input modification, vocabulary learning, input enhancement, input elaboration, reading

\section{INTRODUCTION}

Texts which are primarily written by and for native speakers lack L2 reader-friendly features which can work as an obstacle in the acquisition of vocabulary through the reading activity. Reading as a source of input for EFL learners should possess several features which are often observed in and characterized by face-to-face conversational interaction between proficient and less proficient users of a language. Modification of the reading materials is one way to provide EFL learners with an excellent source of input and boost the learning of vocabulary. The purpose of modification of input, either in spoken or written language, is to increase comprehensibility. Several studies have focused on the effects of input modifications of various types and forms. As Sharwood Smith (1991) puts forward, the type of input received by learners can facilitate their comprehension of the language. One question in SLA research is how modified input boosts the comprehension of EFL learners.

\section{LITERATURE REVIEW}

Text modification intends to facilitate comprehension of the readers and is of three types: input simplification, input elaboration, and input enhancement. Through input simplification, those vocabulary items and grammatical structures which are particularly comprehensible for native speakers are removed from a text, while in input elaboration, as the name suggests, the text remains intact but the definition of the unfamiliar words are given in the text. Also, the sentences with complicated syntactic structures are simplified to enhance the readers' comprehension. However, input enhancement employs bolding, italicizing, or underlining in order to draw learners' attention toward the target structures of the language. Visual input enhancement, as a type of input enhancement, can stimulate learners to pay attention to specific features of language by "manipulation of the written input" (Loewen \& Inceoglu, 2016, p. 90).

Schmidt's (2001) Noticing Hypothesis provides a theoretical justification for applying input enhancement. It is worth mentioning that most of the research studies conducted on input enhancement have focused on language forms rather than vocabulary (e.g., Izumi, 2002; Jahan \&Kormos, 2015; Leow, Egi, Nuevo, \& Tsai, 2003; Rashtchi \& Gharanli, 2010; White, 1998). However, there are studies which have addressed the role of input enhancement in the learning of the second or foreign language vocabulary. One such study is Kim (2006) that manipulated lexical elaboration and textual enhancement to examine whether they could enhance Korean English language learners' incidental vocabulary learning. The result of the study showed that lexical elaboration led the participants to recall the words and structures more effectively. However, Rott (2007) discovered that the frequency of input or semantic enhancement gained by employing glosses was more effective than the modification of input in enhancing the rate of productive vocabulary gain.

Furthermore, among the studies of enhancement, two factors of oral input enhancement and working memory were also found by Sagarra and Abbuhl (2013) to raise the effectiveness of recasts. Using other enhancement techniques and tools has been investigated, as well. Gascoigne (2006), for example, found that the production of second language 
materials embedded with enhancement activities such as reading from an illuminated screen can have powerful effects on language learning. Barcroft (2003) investigated the role of input enhancement in vocabulary learning of English native speakers who were learning Spanish as their second language. The participants were exposed to 24 Spanish new words and their English equivalents. In the first phase of the study, 9 out of 24 words and in the second phase, 3 out of 24 words were enhanced. The results revealed no effect either on the learning rate of the 9 enhanced words or unenhanced words in the first phase of the study. However, a positive effect was noted for enhancing 3 out of 24 words on learning rates for the enhanced words based on some dependent measures.

Bishop (2004) assessed the effects of textual modification or enhancement on noticing and understanding of prefabricated chunks and found that the participants in the experimental group paid more attention to the chunks which were unfamiliar for them and had a significantly better performance on the comprehension test. Later, Gasgoine (2006) found a positive effect on another type of explicit input enhancement and modification in a study that investigated diacritics in beginners learning French and Spanish. In her study, a group of learners (the experimental group) was required to retype a passage in either French or Spanish and then was given key codes showing how to produce diacritics. The results revealed that these students had a significantly higher recall of diacritics than the control group. This finding suggests that explicit measures such as asking students to notice the enhanced forms may be more effective at this level, particularly if combined with repeated and more prolonged exposure to the targeted items.

Input flood, as Han, Park, and Combs (2008) clarify, is another type of enhancement or modification that can add to second language acquisition which grows the salience of a target language feature through artificially modifying its recurrence. An extensive body of studies support the effectiveness of 'input flood' which illustrates that reiteration is a critical element in the process of approaching proficiency in the second language (e.g., Ellis, 2002; Rashtchi \& Mohammad Yousefi, 2017; VanPatten, Williams, \&Rott, 2004). Research on single words shows that input flood helps second language learners experience unknown items before the actual occurrence of learning (Chen \& Truscott, 2010; Pigada\& Schmitt, 2006; Webb, 2007). The Chinese participants in Chen and Truscott's (2010) study, who were learning English were exposed to unknown words which were repeated one, three or seven times in 13 reading passages. Following Webb (2007), the researchers administered seven tests to exploit the diverse aspects of lexical knowledge and came up with the conclusion that at both productive and receptive levels, repetition had a positive impact on learners' learning.

As a consequence of the fact that researchers have developed an interest in 'input flood', Hamed Mahvelati and Mukundan (2012) compared the effect of input flooding (as an implicit input enhancement activity) with consciousness-raising (as an explicit activity) on the learning of lexical and grammatical collocations and found that the participants in the consciousness-raising group performed significantly better than the input flooding group. In another study that focused on input flood, Szudarski and Carter (2014) investigated Polish students' learning of verb-noun and adjective-noun collocations. Two instructional strategies of input flood only, and a combination of input flood with input enhancement were utilized. Both the receptive and productive tests indicated that the integration of input flood and input enhancement is more helpful in second language collocation learning. Choi (2016) also explored the effect of textual enhancement on the learning of collocations and used two passages, one with target collocations enhanced in the text and another passage consisting of unenhanced collocations. Findings showed significantly superior performance in the textually enhanced group in comparison with the control group on the target collocations test. The study also showed that the duration of eye fixation of the groups on the enhanced items which was measured by using eye tracking software was longer for the experimental group and the control group had a better performance in recalling the nonenhanced collocations. The implication of the study was that although textual enhancement could promote noticing the target words, the increased attention might negatively affect the participants' recall of the texts.

Conversely, many studies and research findings illustrate the failure of input enhancement techniques in making a difference in the process of learning certain linguistic items and structures. Leow (2001) explored the effects of textual enhancement and noticing on Spanish formal commands and intake. Thirty-eight native speakers of English who had enrolled in a first-year Spanish language program participated in the study. The same 242-word text was read by both a control group and an experimental group. The experimental group was given a textually modified version, in which all targeted verb forms were underlined, and only the formal imperative morpheme was bolded. The researcher did not find a significant difference between the noticing of experimental and control groups regarding the enhanced features of language or their comprehension of the reading text. Leow also found no significant advantage of the enhancement on the readers' intake.

Izumi (2002) examined whether output and visual input enhancement could facilitate the learning of English relativization by adult ESL learners. The results of his study did not show the priority of input enhancement in the process of learning. Barcroft (2002) explored the effect of semantic and structural elaboration on learning Spanish vocabulary and reported that, intensifying semantic processing can "inhibit one's ability to encode the formal properties of new words" (p. 323). In their study, Leow et al. (2003) examined whether textual modification could be beneficial concerning ESL or EFL learning. The 72 first-year college students who participated in their study were exposed to texts where English present perfect and present subjunctive structures were either enhanced or not enhanced. No significant benefit could be found in textual input enhancement over the unenhanced input in the immediate recognition and comprehension posttests. Combs' (2008) study on topic familiarity and input enhancement indicated that neither 
topic familiarity nor textual input enhancement could have an impact on the learning of the language forms. As Lee and Huang (2008) found out through a thorough review of 16 prior studies and literature search which had been conducted on the effects of 'visual input enhancement on grammar learning,' the second language learners who were provided with the visually-enhanced texts and the ones who were not, had performed almost similarly in grammar learning. Kim's (2010) study intended to explore whether visual input enhancement could increase the salience of unfamiliar English vocabulary while reading. The results revealed that although visual input enhancement helped the learners notice the forms, the rate of unknown vocabulary acquisition within the reading process did not increase.

Petchko (2011) investigated the impact of the textual modification on incidental vocabulary learning while reading among intermediate EFL students. Twelve non-words enhanced in the texts were given to the students in the experimental group, while the control group did not have them. Productive and receptive tests were given to both groups to measure the effects of the treatment regarding the students' recognition of the meanings of words and to examine whether they could remember the meanings of the target items. The results of the posttest showed no significant differences between the groups regarding the recognition of forms and recall of the meanings. In another study conducted by Ertürk (2013) the comparison of pushed output, input processing, and visual enhancement did not show any privilege in favor of visual input enhancement for drawing the participants' attention toward the forms under scrutiny.

Although extensive studies have addressed the efficacy of input enhancement in the acquisition of forms and features, the findings are controversial mainly because of the wide range of different methodologies adopted by researchers (Han et al., 2008). As Han et al. (2008) pointed out, in order to draw any reliable conclusion concerning the role of textual enhancement in attracting learners' attention to form further research is required. Valuable information can be provided on the effectiveness of these techniques, merely by examining their effects separately or in combination.

The purpose of the present study was to determine whether lexical input modification through reading had any statistically significant impact on the improvement of second language vocabulary acquisition of Iranian intermediate level EFL learners. Therefore, it seemed crucial to provide an answer to the following research question:

RQ: Do input modification via lexical elaboration and typographical enhancement and no input modification similarly affect Iranian EFL learners' vocabulary learning?

\section{METHOD}

\section{A. Participants}

Sixty intermediate Iranian EFL learners aged between 18 and 22 years in two intact classes participated in the present quasi-experimental research with non-equivalent control group pretest-posttest design. They were studying TEFL in Islamic Azad University, North Tehran Branch and had taken a reading course in the second semester of their study and were selected based on convenience sampling. As there was no information available to determine the homogeneity of the participants regarding their proficiency level at the outset of the study, a general English proficiency, extracted from the Comprehensive English Language Test (CELT) was administered. The results revealed no statistically significant differences between the groups' general language proficiency before the treatment.

\section{B. Instrumentation}

The researchers used three different instruments for data collection. The first instrument was a general proficiency test which was extracted from the CELT. The test initially consisted of 70 questions and was piloted with 30 TEFL students at the same university. The item facility (IF) and item discrimination (ID) indices of each item were calculated. Sixteen items which had item facility below 0.37 were considered to be too difficult and were discarded from the test. Table I shows the reliability estimates of the three subparts (grammar, vocabulary, and reading) of the test, which were computed through K-R-21 formula. The reliability of the total test signified a high reliable index $(\mathrm{r}=0.82)$. The revised version of the test was used to ensure the homogeneity of the participants.

TABLE I.

THE RELIABILITY OF THE PROFICIENCY SUBPARTS

\begin{tabular}{ccc}
\hline Kubtests & K & KR-21 \\
\hline Grammar & 22 & 0.85 \\
Vocabulary & 15 & 0.81 \\
Reading & 17 & 0.76 \\
\hline
\end{tabular}

The next instrument was a vocabulary pretest. Three weeks before the main study, a group of students at the same level of language proficiency who were studying at the same university was asked to read the unelaborated original texts and write down the words they did not know. The 64 lexical items not known by the participants were selected as the target words for the study. The overall non-recognition rate of the items was 96 percent for 61 lexical items. The next three lexical items which were known by 10 percent of the participants were replaced with low-frequency words. For instance, the noun "awareness" was replaced with "cognizance" which was known by none of the participants.

A vocabulary posttest was used as the third instrument of the study. The achievement test consisted of different sections, including multiple-choice items (20 items), matching items (20 items), and true/false items (20 items). The test 
was piloted with a group of students at the same level of proficiency and from the same university. The items met the Bindex between 0.07 and 0.11 . The dependability of the achievement test was examined by estimating the threshold loss agreement via Subkoviak approach (Brown, 2005). The estimated dependability was 0.83 .

\section{Materials}

Two types of materials were used in this study. Initially, some articles from the Internet (e.g., Readworks.org) which are written by native speakers of English for reading comprehension practice were selected (Appendix A). The unmodified versions underwent two main modification types of "lexical elaboration" and "typographical enhancement" (Appendix B). An example of a target word that is both lexically elaborated and typographically enhanced is shown below where a target word (i.e., wonder) is boldfaced, and its meaning is provided in the form of a definition right after which means.

A sentence of unmodified text:

The Snows of Kilimanjaro are one of the wonders of the natural world.

A sentence of modified text:

The Snows of Kilimanjaro are one of the wonders, which means something remarkable to be admired, of the natural world.

The modified versions of the texts were given to the experimental group, whereas the control group received the original unmodified texts.

\section{Selection of the Target Words}

Those words which their meanings were unknown to the participants were the target words in this study. Additionally, these target words were modified through either elaboration or enhancement. For the participants to acquire these words, the elaborated ones were defined explicitly or implicitly. In order to provide an enhanced input, they were boldfaced as well. As previously stated, in the original texts, the target words were neither elaborated nor enhanced. Thus, the acquisition of L2 vocabulary from modified texts and the unmodified texts was compared.

\section{E. Procedure}

After administering the piloted general proficiency test to the 60 students who were participating in the study and ensuring that the two intact groups were homogeneous at the onset of the study, the groups were randomly assigned to the experimental (Text Modified Group) and the control group (The Text Unmodified Group). The treatment took ten sessions, and each session lasted for 90 minutes. The same teacher taught both classes.

1. The Text Modified Group (TMG)

Each session consisted of two phases of while reading and post-reading activities. During the treatment, the participants were asked to read one version of the modified passages (totally ten passages) and answer the reading comprehension questions without having access to the text (while reading phase). General discussions about the reading passages were conducted in the class by the teacher for about 30 minutes after the reading activities were completed (post-reading phase). The teacher did not provide any explanations regarding the passages or the meaning of the words while reading or when the students were answering the comprehension questions. They could ask their questions during the classroom discussion in the post-reading phase.

2. The Text Unmodified Group (TUMG)

The participants in the control group used unmodified versions of the reading passages. Each session was divided into the three phases of pre-reading, while-reading, and post-reading activities. Each session started with skimming the text by the students (pre-reading phase). The students went through the passages and underlined the words and sentences they did not understand. Then the teacher answered the participants' questions regarding the passage. Afterward, the participants read the texts aloud for the second time and answered the reading comprehension questions while they had access to the main passage (while-reading phase). In the post-reading phase, the teacher conducted classroom discussions and provided some comprehension-check questions to ensure the participants have understood the reading passage.

\section{RESULTS}

In order to find an answer to the research question of the study, the following statistical analyses were performed.

Table II shows the descriptive statistics regarding the standardized proficiency test administered before the advancement of the study. As the table signifies, the distribution of the two groups was normal at the beginning of the study since the obtained values were between \pm 1.96 . 
TABLE II.

DESCRIPTIVE STATISTICS FOR LANGUAGE PROFICIENCY TEST

\begin{tabular}{ccc}
\hline & TUMG & TMG \\
\hline $\mathrm{N}$ & 30 & 30 \\
Mean & 15.67 & 15.50 \\
Median & 15.50 & 15.00 \\
Std. & 4.06 & 4.25 \\
Deviation & 16.50 & 18.12 \\
Variance & .057 & 0.116 \\
Skewness &
\end{tabular}

The Levene's test, as shown in Table III, $(\mathrm{F}=0.02, \mathrm{p}=0.78)$ indicated no statistically significant difference between the variances of the groups. The result of the independent samples t-test, (Table III) also revealed that there was no statistically significant difference between the means of the TMG $(\mathrm{M}=15.50,4.25)$ and the TUMG $(\mathrm{M}=15.67, \mathrm{SD}=$ 4.06) regarding English proficiency $\mathrm{t}(58)=0.24, \mathrm{p}=0.8$ ).

TABLE III.

INDEPENDENT SAMPLES T-TEST FOR PROFICIENCY TEST

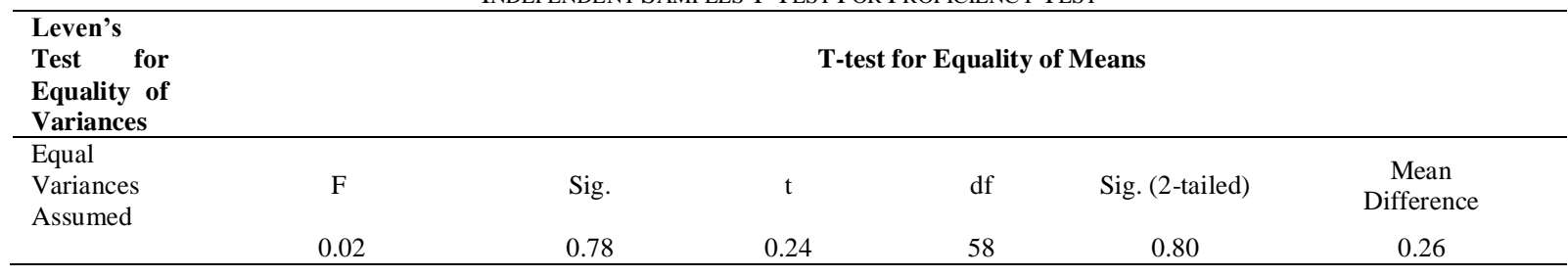

Vocabulary Pretest: The vocabulary pretest, as mentioned above, consisted of a list of words which was administered to the participants of the study to ensure that they did not know the meaning of the target words used in the present study.

Vocabulary Posttest: After the treatment, the participants in both groups sat for the posttest. Then the papers were scored, and the results were analyzed. Table 4 presents descriptive statistics.

TABLE IV

\begin{tabular}{lcc}
\multicolumn{2}{c}{ TABLE IV } \\
& DESCRIPTIVE RESULTS OF GROUPS, POSTTEST \\
\hline $\mathrm{N}$ & 30 & TMG \\
Mean & 15.77 & 30 \\
Std. Deviation & 4.53 & 17.97 \\
Variance & 20.59 & 3.89 \\
Skewness & -.165 & 15.13 \\
\hline
\end{tabular}

The Levene's test, as Table $\mathrm{V}$ indicates, revealed that the two groups were homogenous in terms of their variances $(\mathrm{F}$ $=1.27, \mathrm{p}=0.26)$. The result of the independent samples t-test between the TUMG $(\mathrm{M}=15.77, \mathrm{SD}=4.53)$ and TMG $(\mathrm{M}=17.97, \mathrm{SD}=3.89)$ showed a statistically significant difference between the means of the groups; $\mathrm{t}(58)=2.12, \mathrm{p}=$ 0.03). This result led to the conclusion that the treatment was effective enough to make a significant difference between the means of the TUMG and the TMG groups. Consequently, it could be asserted that lexical elaboration and typographical enhancement had an impact on L2 vocabulary acquisition. The magnitude of the differences in the means (mean difference $=2.33$ ) was moderate (eta squared=0.07).

TABLE V.

INDEPENDENT SAMPLES T-TEST FOR VOCABULARY, POSTTEST

\begin{tabular}{lcccccc}
\hline & $\begin{array}{l}\text { Leven's Test for } \\
\text { Equality of } \\
\text { Variances }\end{array}$ & & T-test for Equality of Means & \\
\hline Equal Variances & $\mathrm{F}$ & Sig. & $\mathrm{t}$ & $\mathrm{df}$ & Sig. (2-tailed) & Mean Differences \\
Assumed & 1.27 & 0.26 & 2.12 & 58 & 0.03 & 2.33 \\
\hline
\end{tabular}

\section{DISCUSSION}

The analysis of the results on the posttest revealed that there was a significant difference in the test scores of the students of TMG, in comparison with TUMG. In other words, the participants in the TMG outperformed the participants in TUMG regarding vocabulary learning. Thus, using lexical elaboration and typographical enhancement as a tool could enhance the vocabulary knowledge of the participants. It can be argued that lexical elaboration and typographical enhancement can be an educational tool which can improve learners' vocabulary knowledge and should be integrated into EFL classes.

This finding can exploit Schmidt (1994), who argued that drawing L2 learners' attention to target language forms can 
help them notice the gap between the current interlanguage and the target language. According to Schmidt's Noticing Hypothesis, "the necessary and sufficient condition for the conversion of input into intake for second language learning to take place" (Schmidt, 1994, p. 17 is learners' noticing to the features of L2 in the written or spoken input. Therefore, the enhancement of the input (Sharwood Smith, 1991; 1993), as was the technique employed in the present study, could draw L2 learners' attention to the intended L2 input. This finding is in line with several studies (e.g., Rassaei, 2015; Rashtchi \& Gharanli, 2010; White, 1998) which have reported that input enhancement could boost learners' performance in different language abilities. However, there are studies which contradict the finding of the present study (Bayonas; 2017; Izumi, 2002; Leow, 2001; LaBrozzi, 2016 Wong, 2003). Also, this study is in contradiction with VanPatten (1990) who found that it is difficult for second language learners especially at the beginning levels to pay attention to both form and meaning at the same time.

Additionally, this study supports the assumption that explicit lexical elaboration, promotes the learning of unfamiliar words inserted in written texts. It can be argued that elaboration provides the necessary input that L2 learners need for learning a second/foreign language. Likewise, it provides EFL/ESL learners with natural discourse models produced by native speakers. Performance of the participants suggests that textual enhancement and elaboration facilitate L2 comprehension at the sentential level, and elaborating target lexical items can facilitate their learning. These findings are consistent with general tendencies found in the previous studies of text modification, L2 comprehension, and vocabulary acquisition (Crossley, Louwerse, McCarthy, \& McNamara, 2007). The present study also finds support from the scholars who assert that simplified input contributes to a higher level of comprehension than unmodified input (e.g., Gass, 2005; Lee, 2007; Long, 2015). Gass (2005) argues that modified language makes the language input comprehensible although she refers to Chaudron (1987) and Yano, Long, and Ross (1994) who have not found that modified input is easier to understand than the unmodified one.

\section{CONCLUSION}

The present study may have implications for pedagogy. Positive effects of lexical elaboration on both comprehension and vocabulary acquisition found in the present study lend support to the use of this technique in teaching vocabulary. An advantage of lexical elaboration is that it can be used with relative ease; adding synonyms to supposedly unknown words will not require much time and effort on the part of the language teachers and/or text writers, yet positive effects on both comprehension and vocabulary acquisition can be expected.

\section{ApPendix A. Global WARMing (UnModified TeXT)}

The Snows of Kilimanjaro are one of the wonders of the natural world. Year-round winter right on the Equator, high on the roof of Africa. But as the world gets warmer, the snows are retreating. Greenpeace members had set up their video-link right on the snow line. Participants in Marrakech could see the shadowy figure of Joris Thijssen perched on bare rock, with snow on the pinnacles behind.

"Hello ladies and gentlemen, welcome to this press conference live from the Kilimanjaro. At the moment I am at approximately five thousand meters high, the roof of Africa..."

Nothing could be more dramatic than the retreat of the Kilimanjaro ice cap. When it was first mapped in 1912, there were twelve square kilometers of ice and snow. Research published at the beginning of this year showed that more than eighty percent of that has now disappeared. A third of the original ice mass has melted in just the last twelve years, and it looks as if the rest of the permanent ice cap could be gone by 2020. If the shining cone of Kilimanjaro melts, the world will have lost something of great beauty. But there will be practical consequences as well. The melting glaciers water the lower slopes of the mountain, and those are the most densely farmed and densely populated parts of Tanzania.

\section{APPENDiX B. Global WARMing (MODIFIED TeXT)}

The Snows of Kilimanjaro are one of the wonders, which means something remarkable to be admired, of the natural world. Year-round winter right on the Equator, high on the roof of Africa. But as the world gets warmer, the snows are retreating. Greenpeace members had set up their video-link right on the snow line. Participants in Marrakech could see the shadowy figure of Joris Thijssen perched, which means sit lightly on the edge of something, on bare rock, with snow on the pinnacles behind.

"Hello ladies and gentlemen, welcome to this press conference live from the Kilimanjaro. At the moment I am at approximately five thousand meters high, the roof of Africa..."

Nothing could be more dramatic than the retreat of the Kilimanjaro ice cap. When it was first mapped in 1912, there were twelve square kilometers of ice and snow. Research published at the beginning of this year showed that more than eighty percent of that has now disappeared. A third of the original ice mass has melted in just the last twelve years, and it looks as if the rest of the permanent ice cap could be gone by 2020. If the shining cone, which means the dazzling white snow and ice on the top of the mountain, of Kilimanjaro, melts, the world will have lost something of great beauty. But there will be practical consequences as well. The melting glaciers water the lower slopes of the mountain, which means the areas of the mountain nearer the ground, and those are the most densely farmed and densely populated parts of Tanzania. 


\section{REFERENCES}

[1] Barcroft, J. (2002). Semantic and structural elaboration in L2 lexical acquisition. Language Learning, 52.2, 323-363.

[2] Barcroft, J. (2003). Effects of questions about meaning during L2 Spanish lexical learning. The Modern Language Journal, 87.4, 546-61.

[3] Bayonas, M. G. (2017). Textual enhancement and the acquisition of the Spanish present subjunctive form. EPiC Series in Language and Linguistics, 2, 14-22.

[4] Bishop, H. (2004). The effect of typographic salience on the lookup and comprehension of unknown formulaic sequences. In N. Schmitt (ed.) Formulaic Sequences. Amsterdam: John Benjamins, 227-248. doi.10.1075/1llt.9.12bis

[5] Brown, J. D. (2005). Testing in language programs. New York, NY: McGraw-Hill.

[6] Chen, C., \& Truscott, J. (2010). The effects of repetition and L1 lexicalization on incidental vocabulary acquisition. Applied Linguistics, 31.5, 693-713.

[7] Choi, S. (2016). Processing and learning of English collocations: An eye movement study. Language Teaching Research, 21.3, 403-426. doi:10.1177/1362168816653271.

[8] Combs, C. (2008). Topic familiarity and input enhancement: An empirical investigation. Working Papers in TESOL and Applied Linguistics, 8.2, 1-51.

[9] Crossley, S. A., Louwerse, M. M., McCarthy, P. M., \& McNamara, D. (2007). A linguistic analysis of simplified and authentic texts. Modern Language Journal, 91.1, 15-30. doi:10.1111/j.1540-4781.2007.00507.x.

[10] Ellis, N. (2002). Frequency effects in language processing: A review with implications for theories of implicit and explicit language acquisition. Studies in Second Language Acquisition, 24.2, 143-188. doi:10.1017/S0272263102002024.

[11] Ertürk, N. O. (2013). Effects of visually enhanced input, output processing and pushed output on grammar teaching. Porta Linguarum, 20, 153-167.

[12] Gass, S. M. (2003). Input and interaction. In C. J. Doughty \& M. H. Long (eds.). The handbook of second language acquisition. Malden, MA: Blackwell, 224-255.

[13] Gascoigne, C. (2006). Toward an understanding of incidental input enhancement in computerized L2environments. CALICO Journal, 24.1, 147-162. http://www.jstor.org/stable/24156298 (accessed 25/4/2018).

[14] Han, Z., Park, E. S., \& Combs, C. (2008). Textual enhancement of input: Issues and possibilities. Applied Linguistics, 24.4, 597-618. doi:10.1093/applin/amn010.

[15] Hamed Mahvelati, E., \& Mukundan, J. (2012). The role of cognitive style in the collocational knowledge development of Iranian EFL learners through input flood treatment. English Language Teaching, 5, 105-117. doi:10.5539/elt.v5n10p105.

[16] Izumi, S. (2002). Output, input enhancement and the noticing hypothesis: An experimental study on ESL relativization. Studies in Second Language Acquisition, 19.2, 541-577. doi:10.1017/S0272263102004023.

[17] Jahan, A., \& Kormos, J. (2015). The impact of textual enhancement on EFL learners' grammatical awareness of future plans and intentions. International Journal of Applied Linguistics, 25.1, 46-66. doi:10.1111/ijal.12049

[18] Kim, M. (2010). Adult ESL Korean readers' responses about their reading in L1 Korean and L2 English. Ph.D. dissertation, The University of Arizona.

[19] Kim, Y. (2006). Effects of input elaboration on vocabulary acquisition through reading by Korean learners of English as a foreign language. TESOL Quarterly, 40.2, 341-373.

[20] LaBrozzi, R. M. (2016). The effects of textual enhancement type on L2 form recognition and reading comprehension in Spanish. Language Teaching Research, 20. 1, 75-91. doi.10.1177/1362168814561903.

[21] Lee, S.-K., \& Huang, H.-T. (2008, September). Visual Input Enhancement and Grammar Learning: A meta-analytic review. Studies in Second Language Acquisition, 30.3, 307-331. https://www.jstor.org/stable/44488690 (accessed 27/3/2019).

[22] Lee, S. L. (2007). Effects of textual enhancement and topic familiarity on Korean EFL students' reading comprehension and learning of passive form. Language Learning, 57, 1, 87-118. doi:10.1111/j.1467-9922.2007.00400.x.

[23] Leow, R. P. (2001). Do learners notice enhanced forms while interacting with the 12?: An online and offline. Hispania, 84.3, 496-509. http://www.jstor.org/stable/3657810 (accessed 20/2/2019). doi:10.2307/3657810.

[24] Leow, R., Egi, T., Nuevo, A., \& Tsai, Y. (2003). The roles of textual enhancement and type of linguistic item in adult L2 learners' comprehension and intake in second language acquisition. Applied Language Learning, 13.2, 1-16.

[25] Loewen, S., \& Inceoglu, S. (2016). The effectiveness of visual input enhancement on the noticing and L2 development of the Spanish past tense. Studies in Second Language Learning and Teaching, 6.1, 89-110. doi: 10.14746/ssllt.2016.6.1.5.

[26] Long, M. (2015). Second language acquisition and task-based language teaching. West Sussex: Wiley \& Sons.

[27] Petchko, K. (2011). Input enhancement, noticing and incidental vocabulary acquisition. The Asian EFL Journal Quarterly, 3.4, 228-255.

[28] Pigada, M., \& Schmitt, N. (2006). Vocabulary acquisition from extensive reading: A case study. Reading in a Foreign Language, 18.1, 1-28. https://nflrc.hawaii.edu/rfl/April2006/pigada/pigada.pdf (accessed 20/3/2019).

[29] Rott, S. (2007). The effects of frequency of input-enhancements on word learning and text comprehension. Journal of Research in Language Learning, 57.2, 166-199. doi.10.1111/j.1467-9922.2007.00406.x.

[30] Rassaei, E. (2015). Effects of textual enhancement and input enrichment on L2 development. TESOL Journal, 6. 2, $281-301$. doi.10.1002/tesj.149.

[31] Rashtchi, M., \& Mohammad Yousefi, L. (2017). Reading input flooding versus listening input flooding: Can they boost speaking skill? Journal of Language and Cultural Education (JoLaCE), 5.1, 39-58. doi:10.1515/jolace-2017-0003.

[32] Rashtchi, M., \& Gharanli, L. (2010). Noticing through input enhancement: Does it affect learning of the conditionals? Journal of Language and Translation, 1.1, 19-27.

[33] Sagarra, N., \& Abbuhl, R. (2013, Spring). Optimizing the noticing of recasts via computer - delivered feedback: evidence that oral input enhancement and working memory help second language learning. The Modern Language Journal, 97.1,196-216. doi:/10.1111/j.1540-4781.2013.01427.x. 
[34] Schmidt, R. (2001). Attention. In P. Robinson (ed.), Cognition and second language instruction. Cambridge: Cambridge University Press, 3-32.

[35] Schmidt, R. (1994). Implicit learning and the cognitive unconscious: Of artificial grammars and SLA. In N. Ellis (ed.), Implicit and explicit learning of languages. London: Academic Press, 165-209.

[36] Sharwood Smith, M. (1991). Speaking to many minds. Second Language Research, 7,118-132.

[37] Smith, M. S. (1991). Speaking to many minds: On the relevance of different types of language information for the L2 learner. Second Language Research, 7.2, 118-132. doi:10.1177/026765839100700204.

[38] Szudarski, P., \& Carter, R. (2014). The role of input flood and input enhancement in EFL learners' acquisition of collocations. International Journal of Applied Linguistics. 26.2. 245-265. doi:10.1111/ijal.12092.

[39] VanPatten, B., Williams, J., \& Rott, S. (2004). Form-meaning connections in second language acquisition. In J. W. B. VanPatten (ed.) Form-meaning connections in second language acquisition. London: Routledge, 1-26.

[40] VanPatten, B. (1990). Attending to form and content in the input: An experiment in consciousness. Studies in Second Language Acquisition, 12, 287-301. doi: 10.1017/S0272263100009177

[41] Webb, S. (2007). The effects of repetition on vocabulary knowledge. Applied Linguistics, 28.1, 46-65. doi:10.1093/applin/aml048

[42] White, J. (1998). Getting the learners' attention. A typographical input enhancement study. In C. Doughty \& J. Williams (eds.) Focus on form in classroom second language acquisition. New York, NY: Cambridge University Press, 85-113.

[43] Wong, W. Y. (2003). The effects of textual enhancement and simplified input on L2 comprehension and acquisition of nonmeaningful grammatical form. Ph.D. dissertation, The University of Illinois.

Mojgan Rashtchi is an associate professor of Applied Linguistics in the faculty of Foreign Languages of Islamic Azad University, North Tehran Branch. She has been working in TEFL for about 27 years and has taught a variety of subjects related to English language teaching to students at different levels. She has published several articles and books and has participated in several local and international conferences. Her primary areas of interest include English language teaching methodology, theories of first and second language acquisition, teaching language skills, and Philosophy for Children (P4C).

Reza Porkar is a Ph.D. candidate in TEFL at Islamic Azad University, North Tehran Branch. He has taught English in different language schools for eight years. Also, he has been lecturing several courses including English Speaking and Listening, English Language Teaching Methodology, First Language Acquisition, and Second Language Acquisition at Islamic Azad University, North Tehran Branch as a temporary contract instructor since 2011. His areas of interest include English language teaching methodology, augmented reality and virtual reality in ESL/EFL settings, and theories of first language acquisition. 